\title{
Antimicrobial properties of preterm breast milk cells
}

\author{
J F MURPHY, M L NEALE, AND N MATTHEWS \\ Department of Child Health and Department of Medical Microbiology, Welsh National School of Medicine
}

SUMMARY The antimicrobial properties of preterm and term breast milk cells were compared. They were similar in cell numbers and in the capacity to phagocytose and kill staphylococci. Interferon production on endotoxin challenge appeared to be higher in preterm cells. The antibacterial activity of breast milk cells was retained after storage at $4{ }^{\circ} \mathrm{C}$ for $24-48$ hours. Cell numbers were unaffected by passage through a standard oral paediatric feeding set.

Recent studies have reported higher concentrations of protein, sodium, and chloride in preterm than in term breast milk. ${ }^{1-3}$ These nutritional differences are thought to be of advantage to the rapidly growing infant. Less is known about the antimicrobial properties of preterm milk. Gross et al. ${ }^{4}$ recently found that preterm milk had higher concentrations of IgA. Narayanan et al..$^{5}$ in a prospective controlled trial found a lower incidence of systemic infections in low birthweight infants fed their mothers' milk. In this study we examined the in vitro antimicrobial properties of preterm breast milk cells.

\section{Patients and methods}

Patients. Paired samples of term and preterm breast milk were obtained from lactating mothers using an Egnell breast pump. All samples were early morning collections made at the beginning of feeds. The gestational age of the preterm infants was 27-34 (mean 31.7) weeks, their birthweights being 700-1900 (mean 1015) g. The gestational age of the term infants was 39-42 (mean 40.5) weeks, their birthweights being 3005-4400 (mean 3590) g. The samples of milk were obtained between days 3 and 7 postpartum.

\section{Methods}

Isolation of cells. Milk samples (10-30 ml) were centrifuged at $500 \mathrm{~g}$ for 5 minutes. The supernatant was discarded and the cells in the pellet were dispersed in $25 \mathrm{ml}$ isotonic, phosphate buffered saline (PBS) and centrifuged again. After two further washes in PBS the cells were resuspended at $2.5 \times 10^{6}$ leucocytes $/ \mathrm{ml}$ in Eagle's minimum essential medium supplemented with $10 \%$ fetal calf serum (MEM/FCS). On each occasion milk samples from a preterm and a term mother were processed synchronously.

Phagocytosis and intracellular killing of Staphylococcus aureus. A penicillin-sensitive strain of Staphylococcus aureus (Oxford) was cultured for 24 hours on blood agar. Bacteria were then suspended in PBS to give a stock suspension with an absorbance of 0.6 at $650 \mathrm{~nm}$. Before use the suspension was diluted 1/100 with MEM/FCS and opsonised by addition of fresh human serum to give a final concentration of $10 \%$ (by vol).

Duplicate mixtures of equal volumes $(250 \mathrm{ml})$ of bacteria and leucocyte suspension were made in screw-topped plastic tubes and then incubated for 30 minutes at $37^{\circ} \mathrm{C}$ in a shaking water bath. The tubes were centrifuged at $500 \mathrm{~g}$ for 5 minutes and the cell pellets resuspended in $0.5 \mathrm{ml}$ MEM/FCS with $100 \mathrm{U} / \mathrm{ml}$ penicillin to kill extracellular bacteria. The cells in one of the duplicate tubes were washed twice with PBS and then lysed with water to release the intracellular bacteria. The number of intracellular bacteria $(=a)$ was then determined by the Miles-Misra method. The other tube was treated similarly after a further 2 hours' incubation at $37^{\circ} \mathrm{C}$; this gives the number of bacteria $(=b)$ surviving within the cells. The percentage of bacteria phagocytosed was calculated from the formula $100 \mathrm{a} / \mathrm{c}$ where $c=$ the original number of bacteria.

An indication of the bactericidal capacity of the leucocytes was made by calculating the percentage of the phagocytosed bacteria which were killed during the 2-hour incubation $(=100(a-b) / a)$.

Interferon assays. Leucocytes, suspended at $2.5 \times 10^{6} / \mathrm{ml}$ in MEM/FCS were incubated overnight at $37^{\circ} \mathrm{C}$ in the presence of $1 \mu \mathrm{g} / \mathrm{ml}$ endotoxin (lipopolysaccharide B from Escherichia coli O26-B6, Difco). The supernatants were collected, centrifuged 
to remove cells, and stored at $-70^{\circ} \mathrm{C}$ until assay. Again a pair of preterm and term cell suspensions was treated in parallel.

Interferon was assayed by an inhibition of cytopathic effect assay using the monkey Vero cell line and encephalomyocarditis virus. A commercial preparation of $\beta$-interferon (Fiblaferon, Flow) was used as a standard. Results are expressed as the highest supernatant dilution causing $50 \%$ inhibition of the viral cytopathic effect.

Adherence of leucocytes to oral paediatric feeding tube. Freshly collected milk $(30 \mathrm{ml})$ was run through an oral paediatric feeding set at a flow rate of $15 \mathrm{ml} / \mathrm{h}$ and collected in a plastic universal container. Samples of milk were taken before and after passage through the tube for determination of cell concentration.

\section{Results}

For both preterm and term milk samples the yield of leucocytes was highly variable, with most samples giving 1-7 $\times 10^{5}$ cells $/ \mathrm{ml}$ although a few samples gave up to $5 \times 10^{6} \mathrm{cells} / \mathrm{ml}$. The relative proportion of neutrophils and macrophages was similar in preterm and term samples. In most samples the predominant cells were macrophages although occasionally up to $70 \%$ of cells were neutrophils. Lymphocytes accounted for fewer than $25 \%$ of the total cells.
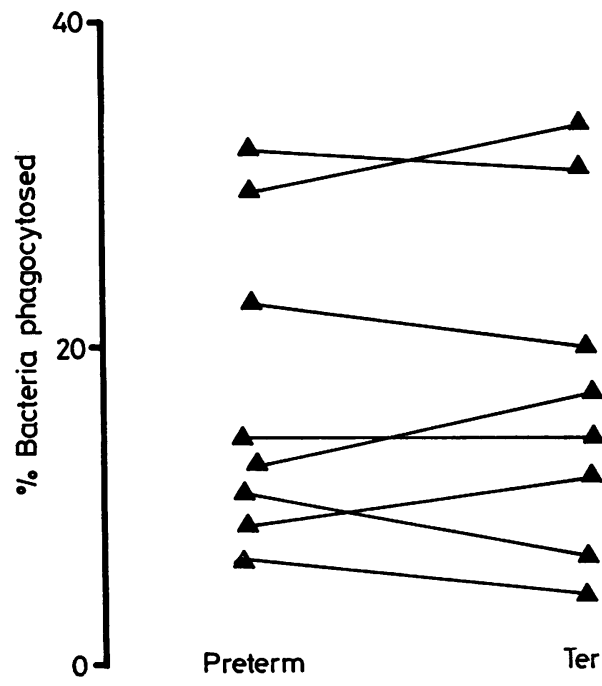

Preterm

Term

Fig. 1 Comparison of phagocytosis of staphylococci by preterm and term milk cells. (The lines join the preterm and term samples in each assay).

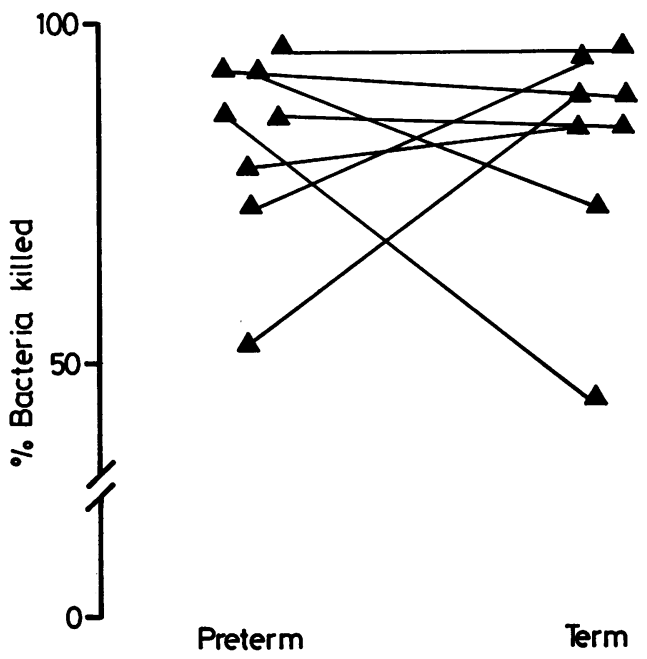

Fig. 2 Comparison of intracellular killing of staphylococci by preterm and term milk cells. (The lines join the preterm and term samples in each assay).

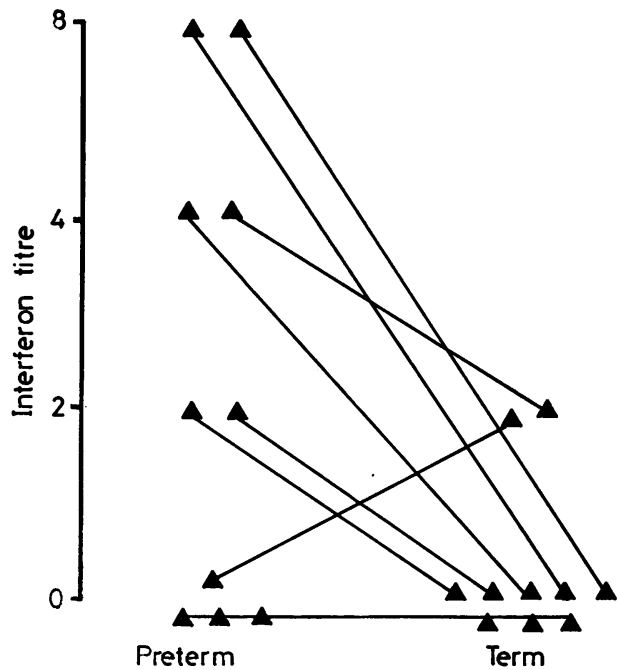

Fig. 3 Comparison of interferon production of preterm and term milk cells. (The lines join the preterm and term samples in each assay).

Cells from preterm and term milk were comparable both in phagocytosis (Fig. 1) and intracellular killing of $S$. aureus (Fig. 2). Because of the interexperimental variation, it was important to include a preterm and a term sample in each assay.

A comparison of endotoxin-induced interferon production is shown in Fig. 3. Although small 
Table Effect of storage of milk at $4^{\circ} \mathrm{C}$ on leucocyte number and function

\begin{tabular}{lllll}
\hline $\begin{array}{l}\text { Experiment } \\
\text { storage }(\mathrm{h}) \\
\text { at } 4^{\circ} \mathrm{C}\end{array}$ & $\begin{array}{l}\text { Length of } \\
\text { recovered } \\
\left(\times 10^{-5} / \mathrm{ml}\right)\end{array}$ & $\begin{array}{l}\text { Bacteria } \\
\text { phagocytosed } \\
\%\end{array}$ & $\begin{array}{l}\text { Phagocytosed } \\
\text { bacteria killed } \\
\%\end{array}$ \\
\hline 1 & 0 & $2 \cdot 3$ & $5 \cdot 3$ & 85 \\
2 & 24 & $1 \cdot 7$ & $3 \cdot 9$ & 74 \\
& 0 & $1 \cdot 1$ & $4 \cdot 1$ & 98 \\
& 24 & 0.7 & $5 \cdot 9$ & 99 \\
& 48 & 0.3 & 6.6 & 99 \\
\hline
\end{tabular}

amounts of interferon were produced by this stimulus, 6 of 10 preterm leucocyte preparations produced detectable amounts of interferon compared with 2 of 10 term ones.

To test the effect of storage on leucocyte bactericidal capacity, milk samples were kept at $4^{\circ} \mathrm{C}$ for 24-48 hours.

On the day of the assay, leucocytes were separated from the stored milk and from a fresh sample of milk from the same mother. The Table shows that although cell recoveries decline on storage of the milk, especially after $\mathbf{4 8}$ hours, the remaining cells are functionally active.

Leucocytes can adhere to plastic and glass surfaces and it is possible that in feeding milk through an oral paediatric feeding set a number of cells are lost by adherence to the plastic tubing. To test this, fresh milk was run through a feeding set at the normal feeding rate and collected in a plastic universal container. At least $95 \%$ of the cells were recovered, indicating that adherence to the feeding tube was not a problem.

\section{Discussion}

Parameters of preterm breast milk cell function have been studied and compared with term breast milk. The preterm and term breast milk cells were equally effective at phagocytosis and intracellular killing of staphylococci. Staphylococcal killing was used because this is a good test of phagocyte function. One noteworthy feature was the degree of interexperimental variation which is greater than that found with blood neutrophils. Hence the importance of paired experiments when working with breast milk cells. In the interferon assays we used an endotoxin because physiologically it is one of the likely stimuli to be encountered in the gut. The preterm breast milk cells performed marginally better but some negative responses were obtained for both preterm and term breast milk cells. Lawton et $a l .^{6}$ have demonstrated the ability of breast cells to produce interferon on stimulation with mitogens or Newcastle disease virus. They did not comment on the reproducibility of this response.

The increasing incidence of neonatal necrotising enterocolitis and the observation that the gut is often the portal of entry in neonatal sepsis has renewed interest in breast milk as a source of immunity. Pitt et al. ${ }^{7}$ have demonstrated the protective action of milk cells in rat enterocolitis. To date, the evidence in human newborn has been less convincing. Kliegman et $a .^{8}$ did not find raw breast milk protective. However, they felt that their techniques of freezing and storage may have reduced cell numbers and functions. In this study we examined the problem of storage and administration of breast milk cells (Table). It appears that the cells will survive for at least 24 hours with only a moderate reduction in numbers and no significant reduction in function. At $\mathbf{4 8}$ hours there is substantial reduction in numbers but cell function is still good. In our unit, milk is given to small preterm infants with the use of paediatric oral feeding sets (Avon Medical Ltd) and nasogastric tubes. We found that cell numbers were unaffected by passage through this feeding system.

If breast milk cells do confer benefits to the neonate's gut immunity, our findings are of practical value. When the mother of a preterm infant provides milk the cells are biologically active and short-term storage and administration can be achieved without compromising their function.

\section{References}

1 Atkinson S A, Bryan M H, Anderson G H. Human milk: difference in nitrogen concentration in milk from mothers of term and premature infants. $J$ Pediatr 1978; 93: 67-9.

2 Schanler R J, Oh W. Composition of breast milk from mothers of premature infants as compared to breast milk obtained from donors. J Pediatr 1980; 96: 679-81.

3 Gross S J, David R J, Bauman L, Tomarelli R M. Nutritional composition of milk produced by mothers delivering pre-term. J Pediatr 1980; 96: 641-4.

4 Gross S J, Buckley R H, Wakil S S, McAllister D C, David $R$ J, Faix $R$ G. Elevated IgA concentration in milk produced by mothers delivered of preterm infants. J Pediatr 1981 ; 99: 389-93.

5 Narayanan I, Prakash K, Gujral V V. The value of human milk in the prevention of infection in the high risk low birth weight infant. J Pediatr 1981: 99: 496-8.

6 Lawton J W M, Shortridge K F, Wong R L C, Ng M H. Interferon synthesis by human colostral leucocytes. Arch Dis Child 1979; 54: 127-30.

7 Pitt J, Barlow B, Heind W C. Protection against experimental necrotizing enterocolitis by maternal milk; role of milk leukocytes. Pediatr Res 1977; 11 : 906-9.

8 Kliegman R M, Pittard W B, Fanaroff A A. Necrotizing enterocolitis in neonates fed human milk. $J$ Pediatr 1979; 95: 450-3.

Correspondence to Dr J F Murphy, Department of Child Health, University Hospital of Wales, Heath Park, Cardiff CF4 4XW.

Received 24 September 1982 